\title{
Pengaruh Komunikasi Sosial Guru Terhadap Minat Belajar Siswa Di SMAN 1 Soromandi
}

\author{
Nurhasanah $^{1}$ Buana Bima Fikri ${ }^{2}$ \\ Program Studi Pendidikan Sosiologi STKIP Bima \\ Jalan Piere Tendean Kel. Mande Tlp.Fax (0374) 42801, Bima 84191, Indonesia \\ (Email; bimabuana212@gmail.com)
}

\begin{abstract}
Abstrak
Komunikasi sosial guru adalah melibatkan guru dalam komunikasi baik secara langsung maupun tidak langsung yang dilakukan guru terhadap siswa dan sahabat sehubungannya, namun komunikasi yang baik oleh guru terhadap siswa akan berpengaruh terhadap minat belajar siswa penelitian ini bertujuan untuk mengetahui seberapa besar pengaruh komunikasi sosial guru terhadap minat belajar siswa di SMAN 1 Soromandi. Jenis penelitian ini adalah penelitian lapangan (fied recerch) kuantitatif pada regiusi dengan menguji pengaruh variabel $X$ dan terhadap variabel $Y$. adapun pendekatan yang digunakan dengan pendekatan regresi linear sederhana, tehnik yang digunakan angket, dokumentasi, observasi dan sampel yang diambil sebanyak 24 siswa. Kemudian diambil berdasarkan rumus regresi korelasi, determinasi uji t untuk mengetahui tingkat signifikan. Hasil penelitian ini menggunakan dari hasil perhitungan product moment=0,645 menggunakan rumus regresi sederhana korelasi $=40,8+45,8$ determinasi untuk mengetahui seberapa besar pengaruh komunikasi sosial guru terhadap minat belajar siswa $=42,8$ sedangkan uji- $t=1,016$ dan dibandingkan dengan $t_{\text {tabel }}$ pada taraf signifikan $5 \%$ uji satu pihak dengan $d k=N$ $2=24-2=22$ maka $H_{O}$ ditolak dan $H_{a}$ diterima, maka uraiannya tidak ada pengaruh komunikasi sosial $X$ terhadap minat belajar siswa Y di SMAN 1 Soromandi.
\end{abstract}

Kata Kunci : Komunikasi Sosial, Guru, Minat Belajar Siswa. 


\section{Pendahuluan}

Pendidikan sangat dibutuhkan bagi negara maju maupun berkembang, karena untuk mengubah suatu negara tidak mungkin lepas dari pendidikan. Pendidikan bisa mengubah kepribadian dan pengetahuan masyarakat dari yang awalnya tidak tau menjadi tahu,mengerti dan diterapkan dikemudian hari. Dalam hal ini yang utama adalah guru dan siswa. Guru memiliki peran utama dalam setiap kegiatan pembelajaran maupun dalam kegiatan luar lingkungan sekolah. Guru menaruh sebagian hidupnya dengan mengajar, jadi separuh waktu guru hanya digunakan untuk bertemu dengan siswanya, oleh karena itu menjadi gurubukanlah hal yang mudah, karena tugas seorang guru bukanlah hanya dengan mengajar lalu selesai, akan tetapimenjadi teladan bagi siswanya sehingga segala tingkah laku yang dimiliki oleh guru.

Menurut Undang-Undang Republik Indonesia Tahun 2005 Tentang Guru Dan Dosen, dijelaskanbahwa"kompetensi adalah seperangkat pengetahuan, keterampilan, dan perilaku yang harus dimiliki, dihayati, dan dikuasai oleh guru atau dosen dalam melaksanakan tugas keprofesional". Dalam kegiatan apapun komunikasi merupakan hal yang wajib untuk dimiliki setiap orang, begitu juga dengan seorang guru. Dalam mendidik guru haruslah memiliki komunikasi yang baik dengan peserta didik agar tidak terjadi kesalahpahaman dan kejenuhan di kelas ketika mengajar. Sehingga mampu berkomunikasi dan bergaul secara efektif dengan siswa, sesama pendidik, tenaga pendidikan, orangtua dan wali peserta didik.

Berdasarkan observasi awal mengatakan bahwa komunikasi sosial guru pada siswa-siswi SMAN 1 Soromandi, seperti kita ketahui bahwa kemampuan tiap-tiap guru dalam berkomunikasi baik verbal maupun non verbal itu berbedabeda. Hal ini bisa kita lihat dari segi kemampuannya berkomunikasikan materi pelajaran, intonasi suara, sistematisasipenyajian materi, ekspresinya, kedisiplinannya, cara guru memberikan respon pada siswa, serta cara guru menarik minat belajar siswa saat proses pembelajaran berlangsung.

Pengamatan yang dilakukan guru yang berada di sekolah memiliki komunikasi yang sangat baik, demikian halnya komunikasi sosial yang dimiliki, dalam kegiatan belajar mengajar termasuk dalam komunikasi dengan siswa, guru mengajar dengan bahasa yang mudah dipahami oleh siswa sehingga akan memudahkan siswa memahami materi pelajaran yang disampaikan oleh guru. Selain komunikasi dengan siswa, guru juga berkomunikasi dengan sesama guru, hal ini terlihat dari cara interaksi mereka dan juga saling membantu jika ada jam pelajaran yang kosong guru yang lain akan mengisi jam pelajaran tersebut. Guru juga berkomunikasi dengan orang tuasiswa, hal ini terlihat ketika ada orang tua siswa yang ke sekolah disambut dengan baik oleh guru, ketika ada pemberitahuan tentang kegiatan sekolah seperti libur, masuk sekolah, pengambilan rapot dan lain sebagainya selain mengabarkan melewati surat yang dititipkan kepada siswa, guru juga memberikan kabar via sms atau telepon.

Komunikasi sosial guru memiliki pengaruh besar terhadap tinggi dan rendahnya minat belajar siswa, karena semakin tinggi komunikasi sosial guru maka semakin tinggi pula minat belajar siswa. Sebaliknya semakin rendahnya komunikasi sosial guru, maka semakin kecil minat belajar siswa. Meskipun komunikasi sosial guru memiliki peranan yang sangat besar namun perlu di ingat bahwa faktor-faktor lain pun tetap berpengaruh. Meskipun minat belajar siswa yang tinggi apabila dalam diri siswa tidak adanya minat untuk belajar atau mengikuti pelajaran maka minat belajar 
siswa tidak akan berfungsi sebagaimana mestinya. Jadi minat sangat berpengaruh terhadap komunikasi sosial guru.

Secara sederhana, minat adalah rasa lebih suka dan rasa ketertarikan pada suatu hal atau aktivitas. Minat belajarjuga dapat tumbuh apabila situasi belajar yang efektif tercipta di kelasnya. Belajar yang efektif ialah suatu belajar yang memberi kesempatan siswa untuk aktif atau terlibat dalam kegiatan belajar, adanya motivasi guru untuk aktif atau terlibat dalam kegiatan belajar, adanya motivasi guru untuk menimbulkan minat dan perhatian siswa dalam proses belajar mengajar. Komunikasi sosial guru berkaitan dengan minat belajar siswa dalam menerima materi pelajaran atau dalam kegiatan belajar mengajar ada sebagian siswa, kurang semangat dalam menerima pelajaran, siswa cenderung diam, dan hanya sesekali mendengarkan bahkan ada yang sampai tertidur pulas. Ada juga sebagian siswa yang kurang memahami penjelasan guru akan tetapi siswa tidak menanyakan apa yang tidak dipahami, hal ini dilihat dari ketika guru menanyakan kembali materi yang telah disampaikan kemudian siswa menjawab tidak paham. Begitu juga dengan kehadiran siswa, ada sebagian siswa yang tingkat kehadirannya di sekolah kurang banyak yang tidak masuk tanpa alasan atau alpa.

Manusia adalah mahkluk sosial dengan demikian, manusia tidak akan bisa hidup menyendiri. Jika hidup secara menyendiri ini sengaja ditempuh oleh seseorang akan sulit baginya untuk memperoleh kebahagian karena telah menyalahi fitrah dalam kehidupannya. Makhluk sosial harus mempunyai kemampuan dalam berkomunikasi sehingga bisa menjalin hubungan dengan orang lain. Namun alangkah menyedihkannya ternyata tidak semua orang mempunyai kemampuan dalam komunikasi secara baik. Sekolah merupakan salah satu institusi pendidikan yang mempunyai peran untuk mencerdaskan kehidupan bangsa para penerus pemimpin bangsa mulai dilahirkan disini melahirkan para calon-calon penerus pemimpin bangsa bukanlah sebuah pekerjaan yang mudah diperlukan suatu perjuangan dan kapasitas seorang pendidik yang mempunyai kemampuan dalam mencapai ilmu kepada peserta didik sangat diperlukan agar tercapainya keefektifan belajar. Guru dalam hal ini dituntut harus mempunyai kemampuan komunikasi yang baik kurangnya komunikasi akan menghambat kepribadian. Apa jadinya jika seorang pendidik tidak memiliki komunikasi yang baik dengan peserta didik hal ini pastilah berdampak pada kepribadian siswa. Apakah siswa yang didik akan mempunyai kepribadian yang baik atau tidak tergantung dengan kemampuan komunikasi guru yang dilakukan peserta didik. Fenomena yang terjadi diatas, peneliti tertarik untuk lebih meneliti lebih mendalam tentang komunikasi sosial guru terhadap minat belajar siswa, peneliti mengambil judul "Pengaruh komunikasi sosial guru terhadap minat belajar siswa di SMAN 1 Soromandi".

\section{Tinjauan Pustaka}

\section{Komunikasi Sosial Guru}

a. Pengertian Komunikasi Sosial Guru Komunikasi dalam istilah bahasa inggris communication berasal dari kata latin communication dan bersumber dari kata communis yang berarti sama. Samadisini maksudnya adalah sama makna.Dalam komunikasi yang melibatkan dua orang, komunikasi berlangsung apabila adanya kesamaan makna(Effendy, 2004:9). Sedangkan menurut shannon dan wheaver dalam hafied cangara (2006:19). mengungkapkan bahwa komunikasi adalah bentuk interaksi manusia yang saling mempengaruhi satu sama lainnya, sengaja atau tidak 
sengaja, tidak terbatas pada bentuk komunikasi menggunakan bahwa verbal, tetapi juga dalam hal ekspresi muka, lukisan, seni dan teknologi. Menurut Suharsimi Arikunto mengemukakan komunikasi social mengharuskan guru memiliki kemampuan komunikasi sosial yang baik dengan peserta didik, sesama guru, kepala sekolah, pengawai tata usaha dan orang tua siswa itu sendiri.

b. Proses Komunikasi Sosial Guru Berdasarkan dari prosesnya, pendidikan merupakan komunikasi dimana bertemukan dua kompunen yang terdiri atas manusia, yakni pengajar komunikator dan pelajar sebagai komunikan. Pada seluruh tingkatan pendidikan formal, pengajar biasanya disebut dengan guru, sedangkan pelajar adalah siswa. Komunikasi dan pendidikan memiliki sebuah perbedaan, perbedaan tersebut terdapat dalam tujuannya. Tujuan komunikasi bersifat umum, sedangkan tujuan pendidikan bersifat khusus (Onong Uchjana Uffendy:2006). Menyampaikan bahwa tujuan pendidikan adalah untuk meningkatkan pengetahuan seseorang mengenai suatu hal sehingga ia mengetahuinya. Namun demikian, ada sebuah hubungan yang erat antara tujuan komunikasi dengan tujuan pendidikan, yakni tujuan pendidikan akan tercapai jika proses komunikatif. Pada umumnya pendidkan berlangsung secara terencana di dalam kelas secara tatap muka (face to face). Karena kelompoknya yang relatif kecil, maka meskipun komunikasi antara pengajar dan pelajar dalam ruangan tersebut bisa dikategorikan sebagai komunikasi kelompok. Sebagi seorang guru bisa saja mengubahnya menjadi komunikasi interpersona. Terjadinya komunikasi dua arah dimana komunikasi terjadi antara (siswa) menjadi komunikan dan pengajar (guru) sebagai komunikator.

Dengan hal ini, seorang guru tidak dituntut untuk memahami halhal yang bersifat filosofis dan konseptual saja. Akan tetapi dalam hal teknisi juga. Dalam hal teknisi meliputi kegiatan mengelolah dan melaksanakan interaksi belajar mengajar. Dalam proses pendidikan sering dijumpai kegagalankegagalan, hal ini biasanya dikarenakan lemahnya sistem komunikasi. untuk itu, pendidikan perlu mengembangkan pola komunikasi pendidikan efektif dalam proses belajar mengajar. Komunikasi pendidikan yang dimaksudkan adalah hubungan atau interaksi antara pendidik dan peserta didik pada saat proses belajar mengajarberlangsung atau dengan kata lain hubungan aktif antara pendidik denga peserta didik.

\section{Minat Belajar Siswa}

a. Pengertian Minat Belajar Siswa

Kata minat secara etimologi berasal dari bahasa inggris"interest" yang berarti kesukaan, perhatian ( kecenderungan hati pada sesuatu), keinginan jadi dalam proses belajar siswa harus mempunyai minat belajar yang berlangsung, karena dengan adanya minat akan mendorong siswa untuk menunjukkan perhatian.aktivitasnya dan partisipasi dalam mengikuti belajar yang berlangsung. Menurut slameto (2003:180), " minat adalah kecenderungan yang tetap untuk memperhatikan dan mengenang beberapa keinginan".

Sedangkan belajar Menurut whittaker, (dalam Djamarah, 


\begin{tabular}{lrrr} 
2010:185) merumuskan bahwa & \multicolumn{1}{c}{ Penelitian ini menggunakan } \\
"belajar sebagai proses dimana & pendekatan kuantitatif dengan analisis \\
tingkah laku ditimbulkan atau diubah & korelasi dan regresi. Teknik pengumpulan \\
melalui latihanatau & data yakni angket, observasi dan \\
pengalaman"demikian pula menurut & dokumentasi. Populasi penelitian yakni 24 \\
$\begin{array}{l}\text { Djamarah(2011:13) belajar } \\
\text { merupakan serangkaian kegiatan }\end{array}$ & $\begin{array}{l}\text { orang. Tehnik analisis data yakni regresi } \\
\text { linier sederhana dan uji tingkat segnifikan }\end{array}$ \\
jiwa raga untuk memperoleh suatu & dengan uji-t lalu kesimpulan
\end{tabular}
perubahan tingkah laku sebagai hasil dari pengalaman individu dalam interaksi dengan lingkungannya yang menyangkut kognitif, efektif dan psikomotor. Jadi minat belajar adalah rasa suka/senang,pernyataan lebih menyukai, adanya rasa ketertarikan adanya kesadaran untuk belajar tanpa ada dorongan, berpartisipasi dalam aktivitas belajar memberikan perhatian. Sedangkan menurut Slameto(2002:132) minat belajar adalah perasaan senang, ketertarikan, penerimaan, dan keterlibatan siswa.

b. Faktor- Faktor Yang Mempengaruhi Minat Belajar Siswa

Dalam pengertian sederhana, minat belajar adalah keinginan terhadap sesuatu tanpa ada paksaan. Dalam minat belajar seorang siswa memiliki faktor-faktor yang mempengaruhi minat belajar yang berbeda-beda menurut syah (2003:132) membedakan menjadi 3 macam yaitu:

1) Faktor internal

Faktor internal meliputi dua aspek, yakni: Aspek fisiologis, Aspek psikologis

2) Faktor eksternal terdiri dari dua macam yaitu Lingkungan sosial dan Lingkungan nonsosial. Faktor pendekatan belajar dilihat dari pendekatan guru dalam komunikasi sosial guru dengan siswa.

\section{Metode Penelitian}

\section{Hasil Penelitian}

Penelitian ini untuk mengetahui pengaruh komunikasi sosial guru terhadap minat belajar siswa Berdasarkan hitungan dari hasil analisis product moment, dimana $\mathrm{r}_{\mathrm{xy}}=0,654$ lebih besar dari $\mathrm{r}$ table $=0,404$ $(0,06$ atau $5 \%)$ sehingga memiliki tingkat signifikan untuk uji dua arah antara komunikasi sosial guru variabel (X) terhadap minat belajar siswa variabel $(\mathrm{Y})$ di SMAN 1 Soromandi Kabupaten Bima. Jika mengacu pada tabel interpretasi nilai $r$ maka, maka hasil 0,654 berada pada kategori cukup baik. Artinya kemampuan komunikasi sosial guru terhadap minat belajar siswa pada pengaruh yang cukup baik terhadap minat belajar siswa di SMAN 1 Soromandi Kabupaten Bima.

Sedangkan hasil analisis koefesien determinasi dapat diketahui bahwa kontribusi komunikasi sosial guru terhadap minat belajar siswa cukup baik terhadapminat belajar siswa karena hasil dari nilai koefesien. Hal ini menunjukan bahwa minat belajar siswa sangat baik dalam komunikasi sosial guru akan berpengaruh baik terhadap minat belajar siswa.

Kemudian hasil analisis regresi sederhana diperoleh $\mathrm{Y}=40,8+45,8 \quad \mathrm{X}$ nilai konstanta $\mathrm{a}=40,8$ menunjukan bahwa minat belajar siswa $=40,8$ nilai koefesien regresi (b) pada variabel komunikasi sosial guru sebesar 45,8. Angka ini menunjukan setiap penambahan satuan jenjang variabel komunikasi sosial guru (X), maka akan menyebabkan terjadinya peningkatan variabel minat 
belajar siswa (Y) di SMAN 1 Soromandi Kabupaten Bima.

Dengan demikian bahwa komunikasi sosial guru dengan baik sehingga akan berpengaruh cukup baik terhadap minat belajar siswa, karena dalam komunikasi sosial guru yang lebih berperan dalam mewujudkan minat belajar siswa dan memberikan dorongan atau memotivasi siswa agar memiliki minat dalam belajar.

Komunikasi sosial guru di SMAN 1 Soromandi sudah baik. Hal ini dapat dilihat dari segi cara mengajarnya, penampilannya, kedisplinannya, maupun akhlaknya, itu sudah baik. Selain bisa mendidik, mengajar dan membimbing juga bisa menjadi panutan bagi siswa. berdasarkan hitungan dari hasil analisis product moment, dimana $r_{x y}=0,654 l e b i h$ besar dari $\mathrm{r}$ table $=0,404 \quad(0,6$ atau 5\%)sehingga memiliki tingkat signifikan untuk uji dua arah antara komunikasi sosial guru variabel $(\mathrm{X})$ terhadap minat belajar siswa variabel (Y). Minat belajar siswa di SMAN 1 Soromandi berada dalam kategori "cukup baik".

\section{Kesimpulan}

Adapun kesimpulan dari penelitian tentang Pengaruh Komunikasi Sosial Guru Terhadap Minat Belajar Siswa Di SMAN 1 Soromandi;

- Kemampuan komunikasi sosial guru terhadap minat belajar siswa pada pengaruh yang cukup baik terhadap minat belajar siswa di SMAN 1 Soromandi Kabupaten Bima.

- Hasil analisis koefesien determinasi diketahui bahwa kontribusi komunikasi sosial guru terhadap minat belajar siswa cukup baik terhadapminat belajar siswa karena hasil dari nilai koefesien. Hal ini menunjukan bahwa minat belajar siswa sangat baik dalam komunikasi sosial guru akan berpengaruh baik terhadap minat belajar siswa. Dengan demikian bahwa komunikasi sosial guru dengan baik sehingga akan berpengaruh cukup baik terhadap minat belajar siswa, karena dalam komunikasi sosial guru yang lebih berperan dalam mewujudkan minat belajar siswa dan memberikan dorongan atau memotivasi siswa agar memiliki minat dalam belajar.

\section{Daftar Pustaka}

Achmadi dan Narbuko. 2009. Metodologi Penelitian, Jakarta: Bumi Aksara

Arikunto, 2012. Prosedur penelitian suatu pendekatan praktis. Edisi Revisi VI. Jakarta: PT. Rineka Cipta.

Adkon, dan Ridwan. 2009. Rumus dan Data Dalam Analisis Statistik Untuk Penelitian, Cetakan 3,Alfabeta : Bandung

Arikunto, Suharsimi. 2002. Metodelogi Penelitian PT. Rineka Cipta. Jakarta Adkon, dan Ridwan. 2009. Rumus dan Data Dalam Analisis Statistik Untuk Penelitian, Cetakan 3,Alfabeta : Bandung

Cangara, Hafied 2006. Pengantar Ilmu Komunikasi, Jakarta: PT Raja Grafindo

Djamarah, Syaiful Bahri Dan Aswar Zain. 2010. Strategi Belajar Mengajar. Jakarta: Rineka Cipta.

Djamarah, Syaiful Bahri. 2011. Psikologi belajar. Jakarta: Rineka Cipta

Muhibbin Syah. (2003). Psikologi Belajar. Jakarta: PT. Raja Grafindo Persada

Nana Syaodih Sukmadinata (2010), metode penelitian pendidikan. Bandung: Remaja Rosdakarya.

Onong Uchjana Uffendy. 2006. Ilmu Komunikasi Teori Dan Praktek. Bandung: Penerbit Remaja Rosda Karya.

Sugiyono. (2009) Metode Penelitian Pendidikan Pendekatan Kuantitatif 
Pengaruh Komunikasi Sosial Guru

Kualitatif dan R\&D. Bandung:

Alfabeta

Sugiyono, 2013, Metodologi Penelitian

Kuantitatif, Kualitatif dan R\&D. (bandung:ALFABETA)

Slameto, (2003). Belajar dan factor-faktor yang mempengaruhinya, Jakarta: Rineka Cipta. 